\title{
Analisis Uji Tes Toleransi Glukosa Oral Sebagai Deteksi Dini Pradiabetes Pada Obesitas
}

\author{
${ }^{1}$ Alfyan Rahim \\ ${ }^{2}$ Thaslifa \\ ${ }^{3}$ Irwansyah
}

${ }^{1}$ Program Studi S1 Keperawatan dan Pendidikan Profesi Ners, Universitas Megarezky
${ }^{2}$ Program Studi DIII Teknologi Laboratorium Medis, Universitas Megarezky
${ }^{3}$ Program Studi S1 Keperawatan dan Pendidikan Profesi Ners, Universitas Megarezky

Alamat Korespondensi:

Alfyan Rahim

Keperawatan Medikal Bedah

Universitas Megarezky

081241814255

alfyanrahim23@gmail.com 


\begin{abstract}
ABSTRAK
Latar Belakang: Diabetes Melitus (DM) merupakan salah satu penyakit berbahaya, prevalensi di Indonesia termasuk Sulawesi Selatan hingga saat ini telah mencapai 3,4 \% dari jumlah penduduk. Prediabetes merupakan kondisi awal terjadinya DM dimana kadar glukosa darah berada pada level di atas normal. Beberapa faktor yang paling erat hubungannya dengan kejadian prediabetes yakni obesitas yang juga merupakan masalah yang dihadapi saat ini pada usia anak maupun remaja. Salah satu cara untuk mendeteksi adanya gangguan pada metabolime glukosa yakni Tes Toleransi Glukosa Oral (TTGO). Tujuan: Penelitian bertujuan untuk mengetahui kejadian pradiabetes pada mahasiswa yang menderita obesitas. Metode: Desain penelitian adalah deskriptif analitik yaitu menganalisis variabel Uji TTGO sebagai screening prediabetes pada seluruh mahasiswa yang mengalami obesitas di Universitas Megarezky yang diperoleh dengan cara tehnik purposive sampling. Hasil: Hasil penelitian pada 40 orang responden setelah dilakukan pengukuran kadar GDP dan glukosa setelah dua jam pemberian glukosa oral (postprandial), diperoleh rerata kadar TTGO responden adalah 120,45mg/dl dan 8 (20\%) orang diantaranya memiliki kadar TTGO abnormal (140-199mg/dl). Kesimpulan: Penelitian menunjukkan bahwa ke-8 orang responden tersebut mengalami toleransi glukosa terganggu (TGT) dan menunjukkan prediabetik. Sebaiknya penderita obesitas mulai menjaga keseimbangan antara intake dan energi yang dikeluarkan agar tidak menjadi DM.
\end{abstract}

Kata kunci: Glukosa, TTGO, Pradiabetik, Obesitas, DM

\begin{abstract}
Background : Diabetes mellitus (DM) is one of a dangerous disease with prevalence in Indonesia, including South Sulawesi, until now it has reached $3.4 \%$ of the total population. Prediabetes is an early condition for diabetes where blood glucose levels are above normal levels. Some of the factors that are most closely related to the incidence of prediabetes are obesity which is also a problem currently faced at the age of children and adolescents. One way to detect a disturbance in glucose metabolism is the Oral Glucose Tolerance Test (TTGO). Objective : This study aims to determine the incidence of prediabetes in obese students. Methods : The study design was analytical descriptive, analyzing the test variables of OGTT as a prediabetes screening in the obese. The population was all active students of Megarezky University who were obese obtained by purposive sampling technique. Results : Based on the research result of 40 respondents, after the measured levels of GDP and twohour glucose levels after oral glucose administration (postprandial), obtained a mean grade of respondents OGTT was 120,45mg / dl and 8 (20\%) of whom had an abnormal OGTT level (140-199mg / dl). Conclusion : It reveals that the eight respondents experienced impaired glucose tolerance (IGT) and prediabetes. Obese people should begin to keep a balance between intake and energy expended to avoid Diabetes Mellitus.
\end{abstract}

Keywords : Glucose, OGTT, prediabetic, Obesity, DM 


\section{PENDAHULUAN}

Pada dasarnya para ahli menyimpulkan bahwa diabetes melitus merupakan mother of the disease karna selain diabetes itu merupakan salah satu penyebab kematian tertinggi namun komplikasi dari diabetes itu sendiri bisa menjadi penyebab utama penyakit berbahaya lain seperti gagal ginjal, hipertensi dan stroke yang disebabkan oleh kegagalan sel-sel beta pangkreas untuk menghasilkan insulin yang cukup dalam darah (Smetzer, 2016). Beberapa studi epidemologi yang mempelajari penyebaran dan prevalensi dari kasus tersebut memberikan informasi yang menggambarkan bahwa diabetes selalu meningkat tiap tahunnya seperti yang telah disampaikan oleh WHO pada tahun 2030 diabetes menjadi penyebab kematian ke- 7 dunia (WHO, 2014). International Diabetes Federation (IDF) memperkirakan penderita DM menjadi 592 juta pada tahun 2035. Hal tersebut selain dinegara negara maju seperti Amerika, Jepang, Singapura, namun ternyata kasus tersebut sangat banyak ditemukan di negara-negara berkembang tidak terkecuali Indonesia yang yang sampai sekarang menempati urutan ke-7 dunia (IDF,2014).

Seperti yang telah diuraikan bahwa diabetes akan menjadi masalah yang cukup serius apabila tidak ditangani dengan baik seperti yang disampaikan oleh Badan Pusat Statistik (BPS) ditahun 2003 hanya tercatat 13,7 juta orang dan akan mencapai 20,1 juta orang pada tahun 2030. Hal serupa telah diuraikan oleh World Health Organization yang memperkirakan diabetes menjadi 21,3 juta jiwa dengan penyebaran kasus tersebut hampir diseluruh provinsi Indonesia memiliki prevalensi yang cukup besar, tidak terkecuali Sulawesi Selatan telah mencapai 3,4\% dari jumlah penduduk (Jauhari, 2016).

Sebelum seseorang mengalami Diabetes Mellitus tipe 2, terdapat kondisi yang disebut sebagai prediabetes dengan karateristik terjadi peningkatan glukosa darah melebihi nilai normal, namun belum cukup tinggi untuk dapat didiagnosis Diabetes Melitus. Berdasarkan American Diabetes Association, diagnosis prediabetes dapat ditegakkan salah satunya melalui Tes Toleransi Glukosa Oral (TTGO).

Pradiabetes merupakan masalah yang dihadapi baik di negara berkembang maupun di negara maju sekalipun. Prevalensi prediabetes terlihat seperti fenomena gunung es dikarenakan kondisi individu tersebut tidak merasakan tanda maupun gejala seperti pada penderita Diabetes Melitus. Berdasarkan Riset Kesehatan Dasar 2013, prevalensi kejadian prediabetes di Indonesia tahun 2007 hingga 2013 mengalami peningkatan secara drastis sekitar $26,6 \%$.

Secara teori menyatakan bahwa tingginya prevalensi prediabetes disebabkan oleh beberapa faktor antara lain keturunan, usia, gaya hidup, stres, aktivitas fisik, status gizi, dan lain sebagainya. Namun, beberapa literatur menyatakan bahwa obesitas lebih erat kaitanya dengan resistensi insulin yang menyebabkan meningkatnya kadar gula dalam darah (Fan et al., 2016). 
Walaupun secara teori menyatakan bahwa obesitas sangat erat kaitanya kadar gula dalam darah namun pada kenyataanya penyandang berat badan berlebihan sangat jarang memeriksakan kesehatanya terlebih lagi memeriksakan kadar glukosa dalam darah, seperti studi pendahuluan yang telah dilakukan dari 25 orang mahasiswa di Universitas Megarezky yang mengalami obesitas hanya terdapat 5 orang yang pernah memeriksakan kadar glukosa darahnya, itupun pada saat di rawat di rumah sakit dengan penyakit lain.

Melihat dari fenomena tersebut membuktikan bahwa kesadaran masyarakat terutama penyandang obesitas sangat kurang. Oleh karena itu,

\section{METODE PENELITIAN}

Desain penelitian yang digunakan adalah deskriptif analitik dengan pendekatan survei. Lokasi penelitian berada pada Universitas Megarezky di wilayah kerja Puskesmas Antang Kec. Manggala Kel. Antang dengan waktu penelitian selama satu tahun. Populasi penelitian adalah seluruh mahasiswa yang berstatus aktif dan mempunyai berat bedan berlebih, tidak mempunyai riwayat orang tua penderita Diabetes Melitus, tidak mempunya riwayat penyakit gangguan hormon, dan tidak mengalami gejala klasik diabetes mellitus. Jumlah sampel ditentukan dengan cara perhitungan rumus Slovin yang diperoleh dengan tehnik purposive sampling.

\section{HASIL PENELITIAN}

Penelitian terhadap analisis tes toleransi glukosa oral sebagai deteksi dini prediabetes pada mahasiswa penderita obesitas telah dilakukan pada bulan Juli sampai dengan September 2020. Responden dalam penelitian ini sebanyak 40 orang mahasiswa aktif Universitas Megarezky yang mengalami obesitas. Hasil penelitian dipersentasekan ada tabel berikut;

Hasil penelitian pada 40 orang responden setelah dilakukan pengukuran kadar gdp dan glukosa setelah dua jam pemberian glukosa oral (postprandial), diperoleh rerata kadar TTGO responden adalah $120,45 \mathrm{mg} / \mathrm{dl}$ dan 8 (20\%) orang diantaranya memiliki kadar TTGO abnormal (140-199mg/dl).

Obesitas merupakan suatu keadaan yang menggambarkan adanya ketidakseimbangan antara intake dan energi yang dikeluarkan. Pengukuran antropometri obesitas antara lain pengukuran Indeks Massa Tubuh (IMT) dengan mengukur berat badan $(\mathrm{kg})$ atau pengukuran lingkar pinggang (waist circumference)/panggul (waist hip ratio) dibandingkan dengan tinggi badan $\left(\mathrm{m}^{2}\right)$ yang disesuaikan dengan usia yang digunakan sebagai indikator kejadian obesitas terhadap penyakit degeneratif. Subjek dalam penelitian ini sebanyak 40 orang responden dengan IMT keseluruhan tergolong obesitas $\left(\geq 25,00 \mathrm{~kg} / \mathrm{m}^{2}\right)$, dengan jumlah responden laki-laki sebanyak 8 (20\%) orang dan perempuan 32 (80\%) orang (tabel 1). Perempuan lebih berisiko mengalami obesitas dibandingkan pria karena adanya perbedaan aktivitas fisik dan asupan makanan sehari-hari (azkia \& miko wahyono, 2019). selain asupan energi (lemak, protein, dan karbohidrat), frekuensi asupan fast food, faktor 
genetik, pola hidup, aktivitas fisik, lingkungan, dan psikis merupakan berbagai faktor risiko yang dapat mempengaruhi terjadinya obesitas pada remaja (hendra et al., 2016; kosnayani \& aisyah, 2016; kurdanti et al., 2015).

Selain pengukuran IMT, obesitas dapat pula diketahui melaui pengukuran lingkar pinggang (waist circumference) yang dikenal dengan obesitas sentral. obesitas sentral adalah penumpukan lemak berlebih yang terakumulasi di daerah perut. menurut international diabetes federation (IDF) bahwa kriteria lingkar pinggang obesitas pada laki-laki yaitu $>90 \mathrm{~cm}$ dan perempuan $>80 \mathrm{~cm}$ (sucitawati et al., 2019). penelitian (oemiyati \& rustika, 2015) menggambarkan bahwa perempuan dengan lingkar pinggang $>80 \mathrm{~cm}$ berisiko 1,5 kali (CI 95\%, 1,147-2,221) terhadap penyakit jantung koroner (PJK) dibandingkan yang mmemiliki lingkar pinggang $<80 \mathrm{~cm}$. Menurut Dewi \& Wande (2017) menggambarkan adanya hubungan yang signifikan ukuran lingkar pinggang terhadap kadar glukosa darah sewaktu dan tekanan darah. Wanita obesitas memiliki hubungan yang kuat 3-6 kali berisiko mengalami hipertensi dibandingkan wanita dengan berat badan normal (agustina sapta ningrum, 2018; hendra et al., 2016; salam, 2010).

Indeks Massa Tubuh (IMT) dan lingkar pinggang memiliki hubungan yang bermakna terhadap tekanan darah, kadar glukosa, dan kadar trigliserida. Selain itu, dapat berguna dalam mendeteksi terjadinya beberapa faktor risiko metabolik pada pria dan wanita (liu et al., 2011; sucitawati et al., 2019). Sebuah penelitian yang telah dilakukan oleh Jalal et al., n.d. (2008) menunjukkan terdapat 22,8\% responden yang telah mengalami sindrom metabolik yang disertai dengan asupan energi tinggi. Selain itu, peningkatan IMT sekitar 2325 mulai menunjukkan peningkatan terhadap risiko terjadinya hiperkolesterolemia (harahap et al., 2014).

Keadaan obesitas memiliki risiko yang lebih besar dibandingkan dengan non-obesitas untuk terkena penyakit sindrom metabolik, misalnya terjadi kelainan toleransi glukosa terganggu (TGT) yang dapat berakibat pada penyakit diabetes mellitus (DM) tipe 2 . Penelitian liberty, n.d. menggambarkan hubungan obesitas terhadap kejadian prediabetes yang signifikan (OR=2,63).

\section{PEMBAHASAN}

Berdasarkan American Diabetes Association, diagnosis prediabetes dapat ditegakkan salah satunya melalui uji/tes kadar toleransi glukosa oral (TTGO). Hasil TTGO memberikan gambaran tubuh dalam mentoleransi terjadinya peningkatan kadar glukosa dalam sirkulasi sehingga dapat dijadikan sebagai pengukuran penentuan prediabetik dengan nilai rujukan $<140 \mathrm{mg} / \mathrm{dl}$ (normal), 140-199mg/dl (prediabetes), dan $\geq 300 \mathrm{mg} / \mathrm{dl}$ (diabetes). Prediabetes merupakan salah satu wujud sindrom metabolik yang dapat menjadi awal mula DM (Matthew C. Riddle, MD et al., 2018). Hasil penelitian diperoleh rerata kadar TTGO pada subjek penelitian adalah 120,45mg/dl (tabel 1) dan 8 (20\%) orang diantaranya memiliki kadar TTGO abnormal (140-199mg/dl) (tabel 3). Ini 
menunjukkan bahwa ke-8 orang responden tersebut mengalami toleransi glukosa terganggu dan menunjukkan prediabetik. Hasil penelitian digambarkan pula oleh Liberty, n.d. dan Astuti, (2019) yang menyatakan bahwa obesitas memiliki hubungan yang signifikan ( $p$ value $<0,05)$ terhadap kejadian prediabetik. Seseorang yang mengalami obesitas, 3 kali lebih berisiko untuk mengalami prediabetik dibandingkan yang non-obesitas.

Resistensi insulin yang diakibatkan oleh karena obesitas, berkaitan dengan terjadinya peningkatan konsentrasi lipid pada jaringan. Adiposit putih berfungsi sebagai tempat utama penyimpanan energi yang berlebih yang berasal dari intake makanan dan disimpan dalam bentuk trigliserida dan ukuran lipid yang sangat besar. Saat kalori dibutuhkan, trigliserida dengan cepat dapat dihidrolisis oleh lipase (lipolisis) dan asam lemak yang dihasilkan, kemudian diangkut ke jaringan lain untuk dioksidasi di dalam mitokondria sebagai sumber energi. Sedangkan adiposit coklat mengandung trigliserida yang lebih kecil dan berfungsi untuk thermogenesis karena adanya uncoupling protein-1 (ucp-1) yang yang berasal dari oksidasi asam lemak untuk menghasilkan panas. Warna coklat yang dihasilkan berasal dari kandungan mitokondria yang tinggi (guilherme et al., 2008; serra et al., 2013).

Akumulasi lipid yang berlebihan dalam jaringan adiposa menyebabkan hipoksia pada adiposit, stres retikulum endoplasma (RE), dan kematian sel, serta menyebabkan penumpukan asam lemak. Resistensi insulin yang dimediasi oleh asam lemak dapat pula berdampak terhadap organ-organ lain selain adiposa, misalnya hipotalamus, hati, otot rangka, pankreas, dan gastrointestinal. Berdasarkan hasil penelitian bahwa sel adiposit mampu menghasilkan berbagai hormone edokrin dan sitokin inflamasi yang berfungsi sebagai sinyal endokrin, parakrin, dan metabolik. Hormon yang dihasilkan berupa adipokin yaitu leptin, tumor necrosis factor alpha (TNF-a), PAI-1, interleukin (IL-6), complemen (c3/ASP), MIF, angiotensinogen, adiponektin, dan yang berhubungan dengan kejadian resistensi insulin. hormon-hormon tersebut tidak hanya berkaitan dengan insulin tetapi juga berhubungan dengan hipertensi, dislipidemia, dan aterosklerosis. Efek adipokin sitokin inflamasi terhadap reaksi insulin berkaitan dengan kemampuannya dalam mengaktifkan NF- $\kappa b$ yaitu faktor transkripsi yang berperan utama dalam respons inflamasi dan sistem imunitas tubuh. Adipokin menstimulasi efek protein proinflamasi NF- $k b$ dengan memodulasi pelepasan IKB-kinase (IKK) dan c-Jun n-terminal Kinase (JNK) yang dapat mengganggu kerja insulin (sears \& perry, 2015; serra et al., 2013; tataranni, n.d.).

\section{KESIMPULAN DAN SARAN}

Hasil penelitian pada 40 orang responden setelah dilakukan pengukuran kadar GDP dan glukosa setelah dua jam pemberian glukosa oral (postprandial), diperoleh rerata kadar TTGO responden adalah 120,45mg/dl dan 8 (20\%) orang diantaranya memiliki kadar TTGO abnormal (140-199mg/dl). Penelitian menunjukkan bahwa sebanyak 20\% (delapan 
orang) responden mengalami prediabetik yang ditunjukkan dengan hasil toleransi glukosa terganggu (TGT). Sebaiknya penderita obesitas mulai menjaga keseimbangan antara intake dan energi yang dikeluarkan agar tidak menjadi DM.

\section{DAFTAR PUSTAKA}

Agustina Sapta Ningrum, T., 2018. Hubungan Antara IMT, Lingkar Pinggang, RLPP, Dan Persentase Lemak Tubuh Dengan Kejadian Hipertensi. Jurusan Ilmu Kesehatan Masyarakat Fakultas Ilmu Keolahragaan Universitas Negeri Semarang.

Astuti, A., 2019. Usia, Obesitas dan Aktifitas Fisik Beresiko Terhadap Prediabetes. Endurance 4, 319. https://doi.org/10.22216/jen.v4i2.3757

Azkia, F.I., Miko Wahyono, T.Y., 2019. Hubungan Pola Konsumsi Makanan Berisiko dengan Obesitas Sentral Pada Wanita Usia 25-65 Tahun di Bogor Tahun 2011-2012. Jurnal Epidemiologi Kesehatan Indonesia 2. https://doi.org/10.7454/epidkes.v2i1.1 675

Dewi, P.R.A., Wande, I.N., 2017. E-Jurnal Medika,Vol 6 No 10,Oktober 2017 6, 7.

Fan, H., Li, X., Zheng, L., Chen, X., lan, Q., Wu, H., Ding, X., Qian, D., Shen, Y., Yu, Z., Fan, L., Chen, M., Tomlinson, B., Chan, P., Zhang, Y., Liu, Z., 2016. Abdominal obesity is strongly associated with Cardiovascular Disease and its Risk Factors in Elderly and very Elderly
Community-dwelling Chinese. Sci Rep 6, 21521. https://doi.org/10.1038/srep21521

Guilherme, A., Virbasius, J.V., Puri, V., Czech, M.P., 2008. Adipocyte dysfunctions linking obesity to insulin resistance and type 2 diabetes. Nat Rev Mol Cell Biol 9, 367-377. https://doi.org/10.1038/nrm2391

Harahap, H., Widodo, Y., Mulyati, S., 2014. Penggunaan Berbagai Cut-Off Indeks Massa Tubuh Sebagai Indikator Obesitas Terkait Penyakit Degeneratif Di Indonesia. Gizindo 28. https://doi.org/10.36457/gizindo.v28i2 .20

Hendra, C., Manampiring, A.E., Budiarso, F., 2016. Faktor-Faktor Risiko Terhadap Obesitas Pada Remaja Di Kota Bitung. EBM 4. https://doi.org/10.35790/ebm.4.1.2016 .11040

Jalal, F., Liputo, N.I., Susanti, N., Oenzil, F., n.d. Lingkar Pinggang, Kadar Glukosa Darah, Trigliserida dan Tekanan Darah pada Etnis Minang di Kabupaten Padang Pariaman, Sumatera Barat. 2008 43, 9.

Kosnayani, A.S., Aisyah, I.S., 2016. Faktor Risiko Yang Berhubungan Dengan Obesitas Remaja (Studi Pada Mahasiswa Fakultas Ilmu Kesehatan Universitas Siliwangi Tasikmalaya Tahun 2016). . November 4.

Kurdanti, W., Suryani, I., Syamsiatun, N.H., Siwi, L.P., Adityanti, M.M., Mustikaningsih, D., Sholihah, K.I., 2015. Faktor-faktor yang mempengaruhi kejadian obesitas pada remaja. Jurnal Gizi Klinik Indonesia 11 , 179. https://doi.org/10.22146/ijen.22900 
Liberty, I.A., n.d. Hubungan Obesitas dengan Kejadian Prediabetes pada Wanita Usia Produktif 3, 6.

Liu, Y., Tong, G., Tong, W., Lu, L., Qin, X., 2011. Can body mass index, waist circumference, waist-hip ratio and waist-height ratio predict the presence of multiple metabolic risk factors in Chinese subjects? BMC Public Health 11, 35. https://doi.org/10.1186/14712458-11-35

Matthew C. Riddle, MD, George Bakris, MD, Lawrence Blonde, MD, FACP, Andrew J.M. Boulton, MD, David D’Alessio, MD, Mary de Groot, PhD, Eddie L. Greene, MD, Frank B. Hu, MD, MPH, PhD, Steven E. Kahn, MB, ChB, Sanjay Kaul, MD, FACC, FAHA, Derek LeRoith, MD, PhD, Robert G. Moses, MD, Stephen Rich, $\mathrm{PhD}$, Julio Rosenstock, MD, William V. Tamborlane, MD, Judith WylieRosett, EdD, RD, 2018. Professional Practice Committee: Standards of Medical Care in Diabetes-2018. Dia Care 41, S3-S3. https://doi.org/10.2337/dc18-Sppc01

Oemiyati, R., Rustika, R., 2015. Faktor Risiko Penyakit Jantung Koroner (PJK) Pada Perempuan (Baseline Studi Kohor Faktor Risiko PTM) (Risk Factors for Coronary Heart Disease (CHD) in Women [Baseline Cohort Study of Risk Factors for Non Communicable Disease]). Buletin Penelitian Sistem Kesehatan 18, 4755.

https://doi.org/10.22435/hsr.v18i1.427 7.47-55

Salam, A., 2010. Faktor Risiko Kejadian Obesitas Pada Remaja 6, 6.

Sears, B., Perry, M., 2015. The role of fatty acids in insulin resistance. Lipids Health Dis 14, 121. https://doi.org/10.1186/s12944-0150123-1

Serra, D., Mera, P., Malandrino, M.I., Mir, J.F., Herrero, L., 2013. Mitochondrial Fatty Acid Oxidation in Obesity. Antioxidants \& Redox Signaling 19, 269 284. https://doi.org/10.1089/ars.2012.4875

Sucitawati, P.D., Santhi, D.D., Subawa, A.N., 2019. Hubungan antara obesitas sentral dengan kadar Hbalc pada penduduk usia 30-50 tahun di Lingkungan Batursari Desa Bitera, Gianyar. Intisari Sains Medis 10. https://doi.org/10.15562/ism.v10i3.451

Tataranni, P.A., n.d. Pathophysiology of obesity-induced insulin resistance and type 2 diabetes mellitus. diabetes mellitus 7 . 
Tabel 1

Distribusi Frekuensi Subjek Penelitian berdasarkan Karakteristik

\begin{tabular}{lccccc}
\hline \multicolumn{1}{c}{ Karakteristik } & N & \% & Mean & Min & Max \\
\hline Jenis Kelamin & 40 & 100 & & & \\
$\quad$ Laki-laki & 8 & 20 & & & \\
Perempuan & 32 & 80 & & & \\
\hline Usia (th) & & & & & \\
$\quad 18-25$ & 40 & 100 & 21,38 & 18 & 25 \\
\hline IMT (kg/m2) & 40 & 100 & 29,92 & 24,3 & 35,5 \\
Obesitas I & 22 & 55 & 27,72 & 24,3 & 29,8 \\
Obesitas II & 18 & 45 & 32,63 & 30,1 & 35,5 \\
\hline GDP $(\mathrm{mg} / \mathrm{dl})$ & 40 & 100 & 94,65 & 71 & 149 \\
\hline Kadar TTGO (mg/dl) & 40 & 100 & 120,45 & 86 & 165 \\
\hline
\end{tabular}

Tabel 2

Analisa Bivariat Klasifikasi Indeks Massa Tubuh (IMT) dan kadar Toleransi Glukosa Oral (TTGO), Mahasiswa Obesitas $(n=40)$

\begin{tabular}{cccc}
\hline \multirow{2}{*}{ IMT } & \multicolumn{2}{c}{ TTGO } & \multirow{2}{*}{ Total } \\
\cline { 2 - 3 } & $\begin{array}{c}\text { Normal } \\
(\%)\end{array}$ & $\begin{array}{c}\text { Abnormal / TGT } \\
(\%)\end{array}$ & \\
\hline \multirow{2}{*}{ Obesitas I (\%) } & 17 & 5 & 22 \\
& $(53,1)$ & $(25)$ & $(55)$ \\
\hline \multirow{2}{*}{ Obesitas II (\%) } & 15 & 3 & 18 \\
& $(46,9)$ & $(15)$ & $(45)$ \\
\hline \multirow{2}{*}{ Total } & 32 & 8 & 40 \\
& $(80)$ & $(20)$ & $(100)$ \\
\hline
\end{tabular}

Tabel 3

Analisa Bivariat Kadar Glukosa Darah Puasa (GDP) dan Toleransi Glukosa Oral (TTGO), Mahasiswa Obesitas $(n=40)$

\begin{tabular}{|c|c|c|c|}
\hline \multirow[b]{2}{*}{ Kadar GDP } & \multicolumn{2}{|r|}{ TTGO } & \multirow[b]{2}{*}{ Tota } \\
\hline & $\begin{array}{c}\text { Normal } \\
(\%)\end{array}$ & Abnormal / TGT (\%) & \\
\hline Normal (\%) & $\begin{array}{c}30 \\
(93,75)\end{array}$ & $\begin{array}{c}4 \\
(50)\end{array}$ & $\begin{array}{c}34 \\
(85)\end{array}$ \\
\hline Abnormal (\%) & $\begin{array}{c}2 \\
(6,25) \\
\end{array}$ & $\begin{array}{c}4 \\
(50)\end{array}$ & $\begin{array}{c}6 \\
(15)\end{array}$ \\
\hline Total & $\begin{array}{c}32 \\
(80)\end{array}$ & $\begin{array}{c}8 \\
(20)\end{array}$ & $\begin{array}{c}40 \\
(100)\end{array}$ \\
\hline
\end{tabular}

